\title{
Related Transactions, Executive's Salary Gap and Audit Fees
}

\author{
Yin Jun \\ School of management, Wuhan University of Technology,Wuhan 430000, China; \\ 2512244345@qq.com
}

\begin{abstract}
The primary purpose of this study was to reduce the audit fees of listed companies, and how related transactions and executive's salary gap can impact audit fees. From this angel of view, the essay picks listed A share companies in Shenzhen and Shanghai stock exchange as study objects. The study reveals that executives salary gap shows positive correlation with audit fees. Related transactions don't affect the positive relationship between executive's salary gap and audit fees.
\end{abstract}

Keywords: Related transactions, executive’s salary gap, audit fees

\section{Introduction}

Audit fees reflect the audit quality, industry standards, audit services and other information. Listed companies need to pay a large fee each year. In order to cut down costs, how to reduce audit fees?Related transactions and executive's compensation gap are the important factors to measure audit risk.Therefore, this study tries to discuss the relevance of the related transactions, the executive's salary gap and the audit fees,making further improvement on the the existing research results.

\section{Literature and hypotheses}

According to the tournament theory, the promotion of the position is accompanied by the increase of salary, and the enterprise performance will be improved while the salary gap is increasing. When the salary gap is too large, the low salary executives believe they can not achieve their own value or pay and reward do not match.They tend to get private benefits through covert means of related transactions.High salary executives will make greater efforts to improve company performance in exchange for more remuneration, and related transactions will become effective measures at this time, which is a common way for executives to carry out earnings management.The excessive salary gap will increase the amount of the related transactions, and will bring audit risks.This leads to hypothesis:

Taking account of the related transactions,executive's salary gap is positively related to the audit fees.

\section{Method}

\subsection{Sample and data sources}

The author identified 6819 companies listed on either the Shanghai or Shenzhen stock exchange during 2010-2014 five-year period.All data was gathered through CSMAR database. 


\subsection{Variables}

Table1 Variable definition

\begin{tabular}{|l|l|}
\hline Variable & Variable definition \\
\hline Auditfee & The natural logarithm of the total audit expenses \\
\hline Rpt & The amount involved in the related transactions/asset \\
\hline PG & $\begin{array}{l}\text { PG=ln(The average salary of the core executives-The average salary of the non core executives) } \\
\text { of directors and supervisors/6 } \\
\text { The average salary of the non core executives=(executives' annual salary-Total remuneration of } \\
\text { the top 3 members of the board of } \quad \text { directors and supervisors)/(The number of executives-6) }\end{array}$ \\
\hline Top10 & If the audited firms are the top 10 accounting firms, it is set to 1,else 0 \\
\hline Growth & $\begin{array}{l}\text { The annual amount of operating receipt-operating receipt for the previous year )/operating } \\
\text { receipt for the previous year }\end{array}$ \\
\hline Lev & Total assets/Total liabilities \\
\hline Roa & Net margin/Average balance of total assets \\
\hline Size & The natural logarithm of the total assets \\
\hline Shere1 & The shareholding ratio of first major shareholder \\
\hline Dual & If the chairman and the general manager are the same,it is set to 1,else 0 \\
\hline BS & The natural logarithm of the number of board \\
\hline SS & The number of supervisory board \\
\hline Hold & If executive holds share,it is set to 1,else 0 \\
\hline Year & Dummy variable \\
\hline Ind & Dummy variable \\
\hline
\end{tabular}

\subsection{Model}

$$
\begin{aligned}
\text { Auditfee }= & \alpha_{0}+\alpha_{1} P G+\alpha_{2} \text { Rpt } * \text { PG }+\alpha_{3} \text { Size }+\alpha_{4} \text { Hold }+\alpha_{5} \text { Shere } 1+\alpha_{6} \text { Growth }+ \\
& \alpha_{7} \text { Lev }+\alpha_{8} \text { Dual }+\alpha_{9} B S+\alpha_{10} \text { Roa }+\alpha_{11} \text { Top } 10+\alpha_{12} \text { SS }+\sum \text { Year }+\sum \text { Ind } \\
& +\varepsilon
\end{aligned}
$$




\section{Result}

\subsection{Descriptive statistical analysis}

Table2 Descriptive statistical analysis

\begin{tabular}{ccccccc}
\hline variable & $\mathrm{N}$ & mean & $\mathrm{p} 50$ & $\mathrm{sd}$ & $\mathrm{min}$ & $\max$ \\
\hline Auditfee & 6819 & 13.53 & 13.40 & 0.773 & 12.21 & 18.01 \\
PG & 6819 & 12.58 & 12.63 & 0.820 & 10.16 & 15.91 \\
Rpt & 6819 & 0.347 & 0.156 & 1.192 & 0.000178 & 84.89 \\
PG*Rpt & 6819 & 4.326 & 1.950 & 14.07 & 0.00185 & 973.0 \\
Size & 6819 & 21.77 & 21.60 & 1.165 & 19.53 & 28.25 \\
Hold & 6819 & 0.642 & 1 & 0.479 & 0 & 1 \\
Shere1 & 6819 & 0.360 & 0.340 & 0.154 & 0.0898 & 0.894 \\
Growth & 6819 & 0.170 & 0.0726 & 0.874 & -0.911 & 20.30 \\
Lev & 6819 & 0.394 & 0.377 & 0.301 & 0.0153 & 13.26 \\
Dual & 6819 & 0.204 & 0 & 0.403 & 0 & 1 \\
BS & 6819 & 2.179 & 2.197 & 0.195 & 1.609 & 2.890 \\
Roa & 6819 & 0.0463 & 0.0359 & 0.110 & -0.124 & 7.109 \\
Top10 & 6819 & 0.609 & 1 & 0.488 & 0 & 1 \\
SS & 6819 & 3.812 & 3 & 1.232 & 3 & 13
\end{tabular}

From the descriptive statistical analysis, it can be seen that the audit fees of listed companies vary greatly. The difference of executive compensation among different enterprises is obvious.The tendency of listed companies to choose related party transactions is different. From the interaction of PG and Rpt, it can be seen that the difference is more obvious.

\subsection{Correlations among all variables}

Table3 Correlations among all variables

\begin{tabular}{|c|c|c|c|c|c|c|c|c|c|c|c|c|c|}
\hline & Auditfee & PG & Rpt & Size & Hold & Shere1 & Growth & Lev & Dual & BS & Roa & Top10 & SS \\
\hline Auditfee & 1 & & & & & & & & & & & & \\
\hline PG & $0.2720 *$ & 1 & & & & & & & & & & & \\
\hline Rpt & $0.0394 *$ & $-0.0423^{*}$ & 1 & & & & & & & & & & \\
\hline Size & $0.6564^{*}$ & $0.2747^{*}$ & 0.0033 & 1 & & & & & & & & & \\
\hline Hold & 0.0019 & $0.1737^{*}$ & $-0.0868 *$ & 0.0016 & 1 & & & & & & & & \\
\hline Shere1 & $0.1667^{*}$ & -0.0103 & $0.0387^{*}$ & $0.2829 *$ & $-0.1962 *$ & 1 & & & & & & & \\
\hline Growth & -0.0114 & $0.0324 *$ & 0.0088 & 0.0116 & -0.0188 & -0.0131 & 1 & & & & & & \\
\hline Lev & 0.1170* & $-0.0680 *$ & 0.1494* & $0.2119 *$ & $-0.0753^{*}$ & $-0.0306^{*}$ & $0.0281^{*}$ & 1 & & & & & \\
\hline Dual & $-0.0855 *$ & 0.0463* & $-0.0309 *$ & $-0.1569 *$ & $0.1567^{*}$ & $-0.0427 *$ & -0.0114 & $-0.0501 *$ & 1 & & & & \\
\hline BS & $0.1671^{*}$ & 0.1310* & 0.0163 & $0.3014 *$ & $-0.0522 *$ & 0.0125 & -0.0015 & $0.1005^{*}$ & $-0.1950 *$ & 1 & & & \\
\hline Roa & -0.0116 & $0.1127 *$ & $-0.0308 *$ & 0.0005 & $0.0356^{*}$ & $0.0301 *$ & $0.0549 *$ & $-0.1612 *$ & $0.0286^{*}$ & 0.0134 & 1 & & \\
\hline Top10 & 0.1912* & 0.1009* & 0.0053 & $0.1515^{*}$ & $0.0410^{*}$ & 0.0999* & -0.004 & -0.009 & -0.0048 & 0.0666* & 0.0035 & 1 & \\
\hline SS & $0.1591^{*}$ & $-0.0556^{*}$ & $0.0297^{*}$ & $0.2826^{*}$ & $-0.0945^{*}$ & 0.0729* & -0.0083 & $0.1284^{*}$ & $-0.1558 *$ & $0.3337 *$ & -0.0063 & $0.0638^{*}$ & 1 \\
\hline
\end{tabular}

${ }^{*} \mathrm{p}<0.05$

Analyses were conducted in the table.We find that the audit fee, related party transactions (Rpt) and executive compensation gap (PG) show a significant positive correlation at $5 \%$ level of significance.This shows that the higher the general meeting of the executive pay gap makes the audit fee higher,the enlargement of the related party transactions will increase the audit fee, which has rudimentary verified the hypothesis. 


\subsection{Regression analysis}

Table4 Multiple regression analysis with PG and Auditfee

\begin{tabular}{|c|c|c|c|c|}
\hline \multicolumn{5}{|c|}{ Explained variables: Auditfee } \\
\hline & Coef. & Std.Err. & $\mathrm{t}$ & $\mathrm{P}>|\mathrm{t}|$ \\
\hline PG & $0.0696^{* * *}$ & 0.00207 & 33.66 & 0.000 \\
\hline $\mathrm{PG}^{*} \mathrm{Rpt}$ & $0.00233^{* * *}$ & 0.000682 & 3.410 & 0.001 \\
\hline Size & $0.408 * * *$ & 0.0570 & 7.160 & 0.000 \\
\hline Hold & $-0.0579 * * *$ & 0.0155 & -3.730 & 0.000 \\
\hline Shere1 & $-0.106 * * *$ & 0.00968 & -10.99 & 0.000 \\
\hline Growth & 0.00303 & 0.00577 & 0.530 & 0.599 \\
\hline Lev & -0.00670 & 0.0199 & -0.340 & 0.736 \\
\hline Dual & $-0.0195 * * *$ & 0.00619 & -3.150 & 0.002 \\
\hline BS & $-0.0527 * *$ & 0.0253 & -2.080 & 0.037 \\
\hline Roa & -0.0481 & 0.0350 & -1.370 & 0.170 \\
\hline Top10 & $0.144^{* * *}$ & 0.0215 & 6.730 & 0.000 \\
\hline SS & 0.00366 & 0.00629 & 0.580 & 0.560 \\
\hline cons & $3.172 * *$ & 1.230 & 2.580 & 0.010 \\
\hline year & & & & \\
\hline Ind & & & & \\
\hline R-squared & & & & \\
\hline $\mathrm{F}$ & & & & \\
\hline Prob $>F$ & & & & \\
\hline
\end{tabular}

The model passed 1\% significant levels. From the regression estimation results of executive compensation gap and audit fees, we can see that the regression coefficient of executive pay gap (PG) is significantly positive at $1 \%$ level. At the same time, the regression coefficient of the interaction between the related party transaction and the executive compensation gap is 0.0353 , and the correlation is positive under the significant level of $1 \%$.This shows that in the case of different levels of related party transactions, the large gap in executive pay gap promotes the increase of audit fee. No matter whether the related party transactions are abnormal or not, the executive pay gap is positively related to the audit fee. The hypothesis is set up.

\section{Conclusion}

This paper empirically analyzes the mechanism of executive compensation gap, the interaction of related party transactions and executive compensation gap on audit fees. The results show that: (1) the compensation gap of senior executives is positively related to the audit fees without considering the related party transactions. (2) in the case of related party transactions, the executive compensation gap is also positively related to the audit fees. This shows that the related party transactions do not affect the positive relationship between the executive pay gap and the audit fees.

\section{References}

[1]Ni Xiaoya,Dai Deming,Zhang Dongxu. Equity incentive and audit fees--Empirical Evidence from China[J]. Auditing Research,2017,(01):69-77.

[2]Cai Chun,Xie liufang,Make nana. Executive audit background, earnings management and abnormal audit fees[J]. Accounting Research,2015,(03):72-78+95.

[3]He Weifeng,Liu Wei. Enterprise manager's ability and audit fees[J].Accounting

Research,2015,(01):82-89+97. 
[4]Zhang Junrui,Liu Hui,Yang Bei. The influence of pending litigation on audit fees and audit opinion types[J]. Auditing Research,2015,(01):67-74.

[5]Luo Hong,Zeng Yongliang,Wan Lingyu. Salary scaling, earnings management and executive compensation manipulation[J]. Nankai Business Review,2016,19(02):19-31

[6]Bu Danlu,Zhang Chenyu,Lin Teng. Is promotion expected to reduce the pay gap in state-owned enterprises?[J]. Accounting Research,2017,(01):82-88+96. 